\title{
THE EFFECT OF CEO COMPENSATION, INDEPENDEN DIRECTOR AND AUDIT QUALITY ON TAX AGGRESSIVENESS
}

\author{
Kurnia $^{1}$, Dudi Pratomo ${ }^{1}$, Tommy Handoko ${ }^{1}$ \\ ${ }^{1}$ Telkom University, Bandung, Indonesia, \\ Email : akukurnia@telkomuniversity.ac.id \\ Email : dudipratomo@telkomuniversity.ac.id \\ Email : tommy.handoko97@gmail.com
}

\begin{tabular}{|c|c|}
\hline INFO ARTIKEL & ABSTRAK/ABSTRACK \\
\hline $\begin{array}{l}\text { Histori Artikel : } \\
\text { Tgl. Masuk : } 12 \text { Maret } 2019 \\
\text { Tgl. Diterima : } 26 \text { Maret } 2019 \\
\text { Tersedia Online : } 29 \text { Maret } \\
2019 \\
\text { Keywords: } \\
\text { Tax Agressiveness, Executive } \\
\text { Compensation, Independent } \\
\text { Director, Audit Quality, } \\
\text { Leverage. }\end{array}$ & $\begin{array}{l}\text { Tax is one of the largest sources of revenue from the } \\
\text { State Budget (APBN). Every year it is expected that the } \\
\text { achievement will be in accordance with the targets set by } \\
\text { the government. On the other hand for Taxpayers, tax is a } \\
\text { burden that must be reduced because it affects the profits } \\
\text { earned. Tax avoidance by taxpayers was called tax } \\
\text { aggressiveness, where taxpayers try to minimize the tax } \\
\text { burden in order to increase profits. } \\
\text { This study aims to determine the effect simultaneously } \\
\text { and partially between tax aggressiveness as the dependent } \\
\text { variable with executive compensation, independent director } \\
\text { and audit quality as an independent variable with leverage } \\
\text { control variables that were proxied by a debt to asset ratio } \\
\text { (DAR). } \\
\text { The research method used quantitative research with } \\
\text { descriptive objectives verification and had a type of } \\
\text { causality. The analytical unit used a mining company that } \\
\text { was consistently listed on the IDX, consistently publishes } \\
\text { financial statements and did not experience losses during } \\
\text { the study period of } 2011-2017 \text {. Based on these criteria } 8 \\
\text { samples of the company were obtained with a study period } \\
\text { of } 7 \text { years, resulting in } 56 \text { research samples. The method of } \\
\text { data analysis used descriptive statistical analysis and panel } \\
\text { data regression analysis which was assisted by Microsoft } \\
\text { Excel } 2016 \text { and E-Views } 10 \text { Student Version software. } \\
\text { From the results of descriptive statistical analysis and panel } \\
\text { data regression it was concluded that executive } \\
\text { compensation, independent directors and audit quality had } \\
\text { an effect on simultaneously on tax aggressiveness. } \\
\text { Partially, executive compensation and independent } \\
\text { directors had no effect on tax aggressiveness, while audit } \\
\text { quality had a significant negative effect on tax } \\
\text { aggressiveness. This shows that taxpayers must pay } \\
\text { attention to the independent variable of audit quality } \\
\text { because it could affect tax aggressiveness. }\end{array}$ \\
\hline
\end{tabular}

\section{PENDAHULUAN}

Pada Undang-Undang No. 28 Tahun 2007 tentang Ketentuan Umum dan Tata Cara Perpajakan Pasal 1 ayat (1), pajak merupakan iuran wajib pajak kepada negara yang bersifat memaksa dan seluruhnya digunakan untuk menunjang kehidupan masyarakat luas. Pajak merupakan sumber pendapatan negara paling besar. Pemerintah melakukan pembiayaan untuk kesejahteraan rakyat, seperti peningkatan kualitas pendidikan dan kesejahteraan rakyat, pembangunan infrastruktur untuk kemudahan distribusi kebutuhan hidup dan juga pembangunan daerah-daerah yang relatif tertinggal.

Pemerintah dengan perusahaan (Wajib Pajak) mempunyai penilaian yang 
berbeda mengenai pajak, dimana pemerintah berusaha memaksimalkan pendapatannya dari sektor pajak karena pajak merupakan pendapatan utama negara sedangkan perusahaan berusaha untuk memperkecil pembayaran pajaknya karena pajak merupakan beban yang harus ditanggung perusahaan.

\section{Tabel 1 \\ Perbandingan Anggaran dan Realisasi Penerimaan Pajak (Dalam Miliar Rupiah)}

\begin{tabular}{|c|c|c|c|c|}
\hline Sumber & 2014 & 2015 & 2016 & 2017 \\
\hline $\begin{array}{c}\text { Anggaran } \\
\text { Penerimaan } \\
\text { Pajak }\end{array}$ & 1.280 .389 & 1.379 .992 & 1.546 .665 & 1.498 .871 \\
\hline $\begin{array}{c}\text { Penerimaan } \\
\text { Perpajakan }\end{array}$ & 1.146 .866 & 1.240 .419 & 1.284 .970 & 1.472 .710 \\
\hline Persentase & $89,57 \%$ & $89,88 \%$ & $83,08 \%$ & $98,25 \%$ \\
\hline
\end{tabular}

Sumber: Badan Pusat Statistik (2018)

Berdasarkan tabel 1, penerimaan perpajakan yang selalu meningkat setiap tahunnya tidak diimbangi dengan pencapaian target yang ditetapkan oleh pemerintah itu sendiri. Pada tahun 2014 hanya mencapai $89,57 \%$, kemudian meningkat $0,31 \%$ pada tahun 2015 menjadi $89,88 \%$. Persentase ini menurun sebesar $6,8 \%$ ditahun 2016 menjadi $83,08 \%$ dan pada tahun 2017 terdapat suatu kemajuan pesat dari penerimaan pajak dibanding tahun-tahun sebelumnya yaitu mencapai $98,25 \%$. Seharusnya pada tahun 2017 juga penerimaan perpajakan bisa dimaksimalkan dengan program tax amnesty di tahun 2016 sampai 2017 , tetapi pada kenyataannya target tersebut tidak dapat dipenuhi. Anggaran yang tidak terpenuhi ini dapat disebabkan oleh praktik-praktik penghindaran pajak ataupun penggelapan pajak yang dilakukan oleh perusahaan dalam rangka menekan nilai pajak terutang dari perusahaan.

Perusahaan yang melakukan praktik penghindaran ataupun penggelapan pajak dapat disebut sebagai perusahaan yang agresif terhadap pajak. Agresivitas pajak sendiri diartikan oleh Lanis dan Richardson dalam Martani, D., \& Rusydi, M. (2014) sebagai usaha manajemen yang bertujuan untuk memperkecil laba kena pajak dengan cara menghindari pajak (tax avoidance), menggelapkan pajak (tax evasion) ataupun keduanya. Penghindaran pajak merupakan usaha memperkecil besar pajak yang harus dibayarkan dengan tidak melanggar peraturan perundang-undangan sedangkan penggelapan pajak merupakan kebalikannya, yaitu dengan melakukan manipulasi laporan keuangan yang pasti bertentangan dengan peraturan yang berlaku (Frank et al. dalam Martani, D., \& Rusydi, M., 2014).

Salah satu kasus yang mengindikasikan adanya agresivitas pajak adalah penemuan ICW berdasarkan data dari Direktorat Jendral Pajak bahwa pada periode pertama program tax amnesty, jumlah WP dari sektor pertambangan yang mengikuti program ini berjumlah 967 WP dari 6001 WP. Pada sektor minyak dan gas bumi dari 1.114 jumlah WP yang mengikuti tax amnesty berjumlah 68 WP. Ini mengindikasikan bahwa ada beberapa Wajb Pajak dari sektor pertambangan dan sektor minyak dan gas bumi terindikasi melakukan penghindaran pajak sejumlah yang mengikuti program tax amnesty. Selain itu, kontribusi penerimaan pajak dari sektor minerba menurun setiap tahunnya dari 2012 sampai 2016 yaitu dari $5 \%$ menjadi $2 \%$. Rasio pajak pada sektor ini juga menurun dari tahun 2011 sebesar $12 \%$ menjadi $3,88 \%$ tahun 2016 . ICW juga mencatat bahwa untuk ekspor batu bara pada sektos minerba tidak dilaporkan sepanjang tahun 2012-2016 yaitu sebesar Rp 365,3 triliun. Hal ini mengakibatkan kerugian negara karena perusahaan tidak melaksanakan kewajibannya yaitu membayar pajak penghasilan maupun royalti (cnnindonesia.com).

Berdasarkan penelitian Halioui, $\mathrm{K}$ et al., (2016) dan Hanafi, U., \& Harto, P. (2014), menyatakan bahwa salah satu faktor yang mempengaruhi perusahaan melakukan tindakan agresivitas pajak adalah kompensasi yang diberikan kepada manajemen dalam tatanan eksekutif. Kompensasi berupa insentif akan mendorong manajemen untuk meningkatkan kinerja perusahaan yaitu menaikan laba dengan tindakan agresif terhadap pajak tanpa memikirkan dampak jangka panjang atas tindakannya. 
Selain itu, Tiaras, I., \& Wijaya, H. (2015) menjelaskan bahwa yang mempengaruhi agresivitas pajak adalah komposisi direktur independen pada jajaran direktur. Direktur independen menurut surat keputusan BEI merupakan direktur yang tidak terafiliasi dengan perusahaan dan tidak memiliki ketergantungan ekonomi terhadap perusahaan tempat ia menjabat. Direktur independen memiliki tugas untuk mengawasi kinerja manajemen agar membuat suatu keputusan yang tidak menyimpang seperti halnya tindakan yang agresif terhadap pajak.

Faktor lainnya yang mempengaruhi agresivitas pajak adalah kualitas audit sesuai dengan penelitian yang dialakukan oleh Nurfadilah dkk, (2016) dan Khairunisa, K. dkk, (2017). Kualitas audit merupakan beberapa kemungkinan yang bisa saja terjadi saat pelaksanaan audit laporan keuangan suatu perusahaan oleh seorang auditor dan menemukan sesuatu temuan seperti pelanggaran pelaporan, kesalahan pencatatan serta melaporkannya dalam laporan keuangan audit (Khairunisa, K. dkk, 2017). Kualitas audit dapat dinilai dari KAP yang memberikan jasa auditnya kepada perusahaan. KAP yang terafiliasi dengan KAP big four dinilai memiliki kualitas yang lebih jika dikomparasikan dengan KAP yang bukan big four, karena KAP big four akan berusaha untuk tetap independen dalam pelaksanaan audit laporan keuangan, sehingga akan bersifat lebih skeptis terhadap laporan keuangan klien sehingga membuat manajemen memiliki ruang yang terbatas untuk melakukan tindakan agresif terhadap pajak.

\section{KERANGKA TEORITIS DAN PENGEMBANGAN HIPOTESIS}

\section{Agresivitas Pajak}

Menurut Lanis dan Richardson dalam Martani, D., \& Rusydi, M. (2014), agresivitas pajak dapat diartikan sebagai usaha manajemen yang bertujuan untuk memperkecil laba kena pajak dengan cara menghindari pajak (tax avoidance), menggelapkan pajak (tax evasion) ataupun keduanya. Seperti yang dijelaskan Mardiasmo (2016:11), agresivitas pajak termasuk dalam perlawanan aktif, yaitu perbuatan secara langsung kepada pemerintah untuk menghindari jumlah pajak yang harus dibayar. Tax Avoidance menurut Lanis dalam Martani, D., \& Rusydi, M. (2014) merupakan usaha yang dilakukan oleh wajib pajak untuk menekan beban pajak atau bahkan menghapus utang pajak dengan tidak melanggar peraturan perpajakan yang berlaku. Cara yang dapat dilakukan untuk menghindari pajak tanpa melanggar hukum adalah dengan memanfaatkan celah-celah dari undangundang perpajakan. Bertolak belakang dengan tax evasion yang merupakan usaha yang sama, yaitu mengurangi atau menghapus utang pajak dengan menyembunyikan keadaan sebenarnya yang secara tidak langsung melanggar peraturan perpajakan yang ada. Agresivitas pajak diproksikan dengan effective tax rate (ETR). Nilai ETR yang rendah atau mendekati nol menandakan beban pajak dibayarkan lebih rendah dari yang seharusnya sehingga mengindikasikan bahwa perusahaan melakukan tindakan agresivitas pajak. Effective tax rate dapat dirumuskan sebagai berikut:

$$
\text { Effective Tax Rate }=\frac{\text { Beban Pajak }}{\text { Laba Sebelum Pajak }}
$$

\section{Kompensasi Eksekutif}

Kompensasi merupakan bentuk imbalan yang diberikan kepada karyawan atas sumbangsih tenaga dan pikiran yang diterima dalam bentuk bayaran (Sunardi, 2015:175). Elemen yang terdapat dalam kompensasi yaitu upah dan gaji dimana upah adalah balas jasa yang diterima dalam bentuk uang berdasarkan jumlah produk yang dihasilkan sedangkan gaji merupakan balas jasa dalam bentuk uang atas dasar periode tertentu, kemudian insentif merupakan motivasi yang diberikan perusahaan dalam bentuk rangsangan uang atau benda lainnya 
untuk peningkatan kinerja. Program benefit dapat berupa potongan harga, asuransi, jasa konsultasi dan lain sebagainya. Di dalam penelitian ini kompensasi eksekutif menjadi salah satu faktor yang mempengaruhi manajemen untuk melakukan tindakan agresif pajak. Seperti penelitian sebelumnya yang dilakukan oleh Hanafi, U., \& Harto, P. (2014) dan Halioui, K. et al., (2016), pengukuran kompensasi yang digunakan adalah logaritma natural dari total kompensasi yang diterima eksekutif. Kompensasi dapat dirumuskan sebagai berikut:

$$
\text { Kompensasi Eksekutif }=\operatorname{Ln}(X)
$$

\section{Direktur Independen}

Direktur independen menurut surat keputusan BEI merupakan direktur yang tidak terafiliasi dengan perusahaan dan tidak memiliki ketergantungan ekonomi terhadap perusahaan tempat ia menjabat. Peraturan ini ditetapkan oleh BEI untuk menjaga agar calon direktur pada perusahaan tersebut tetap independen, tidak memiliki ketergantungan ekonomis dengan perusahaan dan tidak dipengaruhi oleh oknum lainnya. Dengan adanya direktur independen akan mencegah manajemen melakukan tindakan agresif pajak. Dalam penelitian sebelumnya, Santoso, T., \& Muid, D. (2014) dan Fadhila, N. dkk, (2017), pengukuran yang digunakan adalah membandingkan jumlah direktur independen dengan total direktur dalam perusahaan tersebut. Direktur independen dapat dirumuskan sebagai berikut:

$$
\begin{aligned}
& \text { Direktur Independen } \\
& =\frac{\text { Jumlah Direktur Independen }}{\text { Total Direktur }} \times 100 \%
\end{aligned}
$$

\section{Kualitas Audit}

Khairunisa, K. dkk, (2017), menjelaskan bahwa kualitas audit merupakan beberapa kemungkinan yang dapat terjadi saat pelaksanaan audit laporan keuangan perusahaan oleh seorang auditor dan menemukan sesuatu temuan seperti pelanggaran pelaporan, kesalahan pencatatan serta melaporkannya dalam laporan keuangan audit.

Kualitas audit sebuah laporan keuangan dapat dinilai dengan melihat KAP yang memberikan jasa auditnya kepada perusahaan. KAP yang terafiliasi dengan KAP big four dinilai memiliki nilai lebih dalam hal kualitas jika dikomparasikan dengan KAP non big four. Hal ini terjadi karena KAP big four tidak memiliki ketergantungan ekonomi kepada tiap kliennya sebab ukuran KAP yang sudah besar serta memiliki aset yang lebih banyak dan juga KAP tersebut memiliki nama baik yang harus dijaga untuk keberlangsungan KAP tersebut. Oleh karena itu KAP yang termasuk dalam big four akan berusaha untuk menjaga tingkat independennya, sehingga akan bersifat lebih skeptis terhadap laporan keuangan klien sehingga membuat manajemen memiliki ruang yang terbatas untuk melakukan tindakan agresif terhadap pajak terlebih lagi tindakan yang melanggar peraturan yang ada (Nurfadilah dkk, 2016). Kualitas audit diukur dengan variabel dummy, dimana perusahaan yang merupakan klien dari KAP big four mendapat nilai 1 dan perusahaan yang merupakan klien dari KAP non big four mendapat nilai 0 .

\section{Pengaruh Kompensasi Eksekutif Terhadap Agresivitas Pajak}

Kinerja perusahaan semakin baik maka semakin besar pula kompensasi yang diterima oleh eksekutif. Manajemen dapat meningkatkan laba dengan salah satu caranya yaitu menekan besar pajak terutang. Namun keadaan ini dapat disalahartikan oleh beberapa manajer yang tidak bertanggungjawab. Salah satunya untuk kepentingannya mendapatkan kompensasi yang besar, manajer melakukan tindakan agresif pajak dengan menekan besaran beban pajak perusahaan agar laba perusahaan meningkat. Halioui, K. et al., (2016) dan Hanafi, U., \& Harto, P. (2014) berpendapat bahwa terdapat pengaruh positif kompensasi eksekutif terhadap agresivitas pajak karena tidak ada wajib pajak yang 
membayarkan pajaknya secara sukarela, setiap wajib pajak bersifat resistan terhadap pajak, sehingga eksekutif sebagai wajib pajak akan berusaha untuk menekan nilai pajak perusahaan dengan alasan kompensasi yang semakin besar.

\section{Pengaruh Direktur Independen Terhadap Agresivitas Pajak}

Dalam perspektif teori agensi, keberadaan direktur independen yang tidak memiliki keterlibatan dengan internal perusahaan dapat menjadi pengawas jalannya peran dan kinerja eksekutif lainnya yang juga akan memberikan keuntungan pada principle sehingga masalah agensi di perusahaan dapat teratasi. Penelitian Lanis dan Richardson dalam Puspita, S. R. (2015), menjelaskan bahwa direktur memiliki pengaruh negatif terhadap agresivitas pajak karena dengan tingkat independensi yang tinggi dari direktur independen dapat mencegah kemungkinan perusahaan melakukan praktik-praktik yang bertolak belakang dengan hukum termasuk dalam hal perpajakan.

\section{Pengaruh Kualitas Audit Terhadap Agresivitas Pajak}

Kualitas audit sebuah laporan keuangan dapat dinilai dengan melihat KAP yang memberikan jasa auditnya kepada perusahaan. KAP yang terafiliasi dengan KAP big four dinilai memiliki nilai lebih dalam hal kualitas jika dikomparasikan dengan KAP non big four. Hal ini terjadi karena KAP big four tidak memiliki ketergantungan ekonomi kepada tiap kliennya sebab ukuran KAP yang sudah besar serta memiliki aset yang lebih banyak dan juga KAP tersebut memiliki nama baik yang harus dijaga untuk keberlangsungan KAP tersebut. Oleh karena itu KAP yang termasuk dalam big four akan berusaha untuk menjaga tingkat independennya, sehingga akan bersifat lebih skeptis terhadap laporan keuangan klien sehingga membuat manajemen memiliki ruang yang terbatas untuk melakukan tindakan agresif terhadap pajak terlebih lagi tindakan yang melanggar peraturan yang ada (Nurfadilah dkk, 2016).

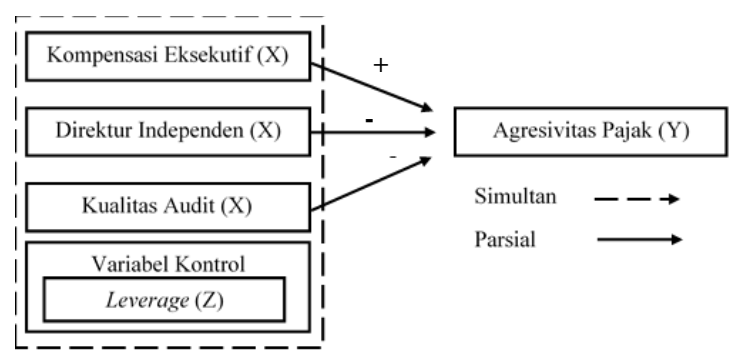

Gambar 1 Kerangka Pemikiran

\section{Hipotesis}

Berdasarkan pembahasan pada kerangka penelitian yang telah diuraikan sebelumnya, maka peneliti mengajukan hipotesis sementara sebagai berikut:

$\mathrm{H}_{1}$ : Kompensasi eksekutif, direktur independen dan kualitas audit berpengaruh secara simultan terhadap agresivitas pajak dengan variabel kontrol leverage.

$\mathrm{H}_{2}$ : Kompensasi eksekutif berpengaruh positif secara parsial terhadap agresivitas pajak.

$\mathrm{H}_{3}$ : Direktur independen berpengaruh negatif secara parsial terhadap agresivitas pajak

$\mathrm{H}_{4}$ : Kualitas audit berpengaruh negatif secara parsial terhadap agresivitas pajak.

\section{METODOLOGI PENELITIAN}

Populasi pada penelitian ini adalah perusahaan pertambangan yang terdaftar di Bursa Efek Indonesia periode 20112017. Sampel dipilih dengan kriteria konsiten listed di BEI, menerbitkan laporan keuangan selama tahun penelitian dan tidak mengalami kerugian selama tahun penelitian. Sehingga diperoleh 8 sampel perusahaan dan periode penelitian adalah 7 tahun sehingga diperoleh jumlah sampel penelitian sebanyak 56 sampel. Pada penelitian ini data dianalisis dengan metode analisis statistik desekriptif dan analisis regresi data panel. Persamaan regresi data panel dalam penelitian ini adalah sebagai berikut:

$$
Y=\alpha+\beta_{1} K E+\beta_{2} D I+\beta_{3} K A+\beta_{4} L E V+e
$$




\section{HASIL DAN PEMBAHASAN}

\section{Statistik Deskriptif}

Tabel 2

Hasil Uji Statistik Deskriptif

\begin{tabular}{|l|c|c|c|c|c|}
\hline & AP & KE & DI & KA & Lev \\
\hline Min & 0.0254 & 22.1549 & 0 & 0 & 0.1449 \\
\hline Maks & 1.1235 & 26.5465 & 0.3333 & 1 & 0.7969 \\
\hline Mean & 0.3759 & 23.9632 & 0.0702 & - & 0.4531 \\
\hline Std.Dev & 0.1817 & 1.0622 & 0.1165 & - & 0.1767 \\
\hline N & 56 & 56 & 56 & 56 & 56 \\
\hline
\end{tabular}

Sumber: Data yang diolah penulis (2019)

Berdasarkan tabel 2 dapat dilihat bahwa variabel dependen agresivitas pajak, variabel independen kompensasi eksekutif dan kualitas audit memiliki nilai mean yang lebih besar dari standar deviasi, yang menggambarkan data yang cenderung berkelompok. Sedangkan direktur independen memiliki nilai mean di bawah standar deviasi, hal ini menunjukkan data yang cenderung tidak berkelompok atau heterogen.

\section{Uji Asumsi Klasik}

Tabel 3

Uji Multikolinieritas

\begin{tabular}{|c|c|c|c|c|}
\hline & KE & DI & KA & Lev \\
\hline KE & 1.0000 & $-0,2017$ & 0,6165 & $-0,2845$ \\
\hline DI & $-0,2017$ & 1.0000 & $-0,1677$ & 0,0446 \\
\hline KA & 0,6165 & $-0,1677$ & 1.0000 & $-0,5454$ \\
\hline Lev & $-0,2845$ & 0,0446 & $-0,5454$ & 1.0000 \\
\hline \multicolumn{5}{|c|}{ Sumber: Output E-Views $10(2019)$}
\end{tabular}

Tabel 3 menunjukkan hasil uji multikolinieritas dengan hasil setiap variabel memiliki nilai di bawah 0,8 atau $80 \%$ sehingga dapat disimpulkan tidak terdapat masalah multikolinieritas.

Tabel 4

Uji Heteroskedastisitas

Heferoskedasticity Test: White

Null hypothesis: Homoskedasticity

\begin{tabular}{llll}
\hline \hline F-statistic & 1.436046 & Prob. F(13,42) & 0.1837 \\
Obs*R-squared & 17.23201 & Prob. Chi-Square(13) & 0.1889 \\
Scaled explained SS & 43.79579 & Prob. Chi-Square(13) & 0.0000 \\
\hline \hline
\end{tabular}

Sumber: Output E-Views 10 (2019)

Berdasarkan tabel 4, uji heteroskedastisitas dilakukan dengan menggunakan metode White dengan hasil Prob Chi-square pada Obs* ${ }^{*}$-square sebesar 0,1889 di atas nilai kritis 0,05 sehingga peneliti menyimpulkan tidak terjadi masalah heteroskedastisitas.

\section{Analisis Regresi Data Panel}

Tabel 5

Hasil Analisis Regresi Data Panel

\begin{tabular}{ccccc}
\hline \hline Variable & Coefficient & Std. Error & t-Statistic & Prob. \\
\hline \hline C & -0.159163 & 0.240818 & -0.660928 & 0.5116 \\
KOMPENSASI_EKSEKUTIF & 0.019770 & 0.010320 & 1.915662 & 0.0610 \\
DIREKTUR_INDEPENDEN & -0.150288 & 0.096555 & -1.556504 & 0.1258 \\
KUALITAS_AUDIT & -0.060994 & 0.018959 & -3.217079 & 0.0023 \\
LEVERAGE & 0.227954 & 0.059883 & 3.806657 & 0.0004 \\
\hline \hline
\end{tabular}

Sumber: Output E-Views 10 (2019)

Menurut tabel 5, diperoleh persamaan regresi data panel sebagai berikut :

$$
\begin{aligned}
\text { ETR }= & -0,159163+0,019770 \mathrm{KE}- \\
& 0,150288 \mathrm{DI}-0,060994 \mathrm{KA}+ \\
& 0,227954 \mathrm{LEV}+e
\end{aligned}
$$

Berdsarakan output tersebut dapat dilihat bahwa:

1. Nilai konstanta sebesar $-0,159163$ yang berarti disaat setiap variabel independen bernilai 0 , maka agresivitas pajak bernilai $-0,159163$ satuan.

2. Koefisien regresi kompensasi eksekutif sebesar 0,019770 menggambarkan ketika terjadi perubahan pada kompensasi eksekutif satu satuan, maka agresivitas pajak akan bertambah sebesar 0,019770 satuan.

3. Koefisien regresi direktur independen sebesar -0.150288 menggambarkan ketika terjadi perubahan pada direktur independen satu satuan, maka agresivitas pajak akan berkurang sebesar 0.150288 satuan.

4. Koefisien regresi kualitas audit sebesar $-0,060994$ menggambarkan ketika terjadi perubahan pada kualitas audit satu satuan, maka agresivitas pajak akan berkurang sebesar 0,060994 satuan.

5. Koefisien regresi leverage sebesar 0,227954 menggambarkan ketika terjadi perubahan pada leverage satu satuan maka agresivitas pajak akan bertambah sebesar 0,227954 satuan.

\section{Uji Simultan (Uji F)}

\section{Tabel 6}


Hasil Pengujian Simultan (Uji F)

\begin{tabular}{llll}
\hline \hline R-squared & 0.327598 & Mean dependent var & 0.626165 \\
Adjusted R-squared & 0.274861 & S.D. dependent var & 0.384788 \\
S.E. of regression & 0.136773 & Sum squared resid & 0.954046 \\
F-statistic & 6.211881 & Durbin-Watson stat & 1.110669 \\
Prob(F-statistic) & 0.000376 & & \\
\hline \hline
\end{tabular}

Sumber: Output E-Views 10 (2019)

Berdasarkan tabel 6 , besar taraf signifikansi prob(F-statistic) sebesar $0,000376<0,05$ yang dapat dinyatakan bahwa variabel kompensasi eksekutif, direktur independen dan kualitas audit berpengaruh secara simultan terhadap agresivitas pajak.

\section{Koefisien Determinasi}

Tabel 6 menunjukkan hasil uji koefisien determinasi $\left(R^{2}\right)$ sebesar 0,274861 atau sebesar 27,4861\%, artinya adalah variabel kompensasi eksekutif, direktur independen dan kualitas audit dengan variabel kontrol leverage mempengaruhi agresivitas pajak sebesar $27,4861 \%$ selebihnya sebesar $72,5139 \%$ dipengaruhi oleh variabel lain di luar variabel penelitian.

\section{Uji Simultan (Uji T)}

Tabel 7

Hasil Pengujian Simultan (Uji F)

\begin{tabular}{crrrr}
\hline \hline Variable & Coefficient & Std. Error & t-Statistic & Prob. \\
\hline \hline C & -0.159163 & 0.240818 & -0.660928 & 0.5116 \\
KOMPENSASI_EKSEKUTIF & 0.019770 & 0.010320 & 1.915662 & 0.0610 \\
DIREKTUR_INDEPENDEN & -0.150288 & 0.096555 & -1.556504 & 0.1258 \\
KUALITAS_AUDIT & -0.060994 & 0.018959 & -3.217079 & 0.0023 \\
LEVERAGE & 0.227954 & 0.059883 & 3.806657 & 0.0004 \\
\hline \hline
\end{tabular}

Sumber: Output E-Views 10 (2019)

Berdasarkan tabel 7, maka dijelaskan bahwa:

1. Variabel kompensasi eksekutif memiliki nilai probabilitas sebesar 0,0610 dengan koefisien bernilai positif, berarti kompensasi eksekutif tidak berpengaruh signifikan terhadap agresivitas pajak.

2. Variabel direktur independen memiliki nilai probabilitas sebesar 0,1258 dengan koefisien bernilai negatif, berarti direktur independen tidak berpengaruh signifikan terhadap agresivitas pajak.

3. Variabel kualitas audit memiliki nilai probabilitas sebesar 0.0023 dengan koefisien bernilai negatif, berarti kualitas audit berpengaruh signifikan dengan arah negatif terhadap agresivitas pajak.

\section{Pembahasan Pengaruh Kompensasi Eksekutif, Direktur Independen dan Kualitas Audit terhadap Agresivitas Pajak}

Berdasarkan tabel 6 besar taraf signifikansi prob(F-statistic) sebesar $0,000376<0,05$, ini menunjukan $\mathrm{H} 0$ ditolak dan $\mathrm{H} 1$ diterima sehingga dapat disimpulkan bahwa variabel kompensasi eksekutif, direktur independen dan kualitas audit dengan variabel kontrol leverage berpengaruh secara simultan terhadap agresivitas pajak pada perusahaan pertambangan yang terdaftar di Bursa Efek Indonesia periode 2011-2017. Adjusted $R$-squared bernilai sebesar 0,274861 yang berarti variabel pada penelitian ini berpengaruh secara simultan sebesar 27,4861\%, variabel tersebut adalah kompensasi eksekutif, direktur independen dan kualitas audit dengan variabel kontrol leverage.

\section{Pembahasan Pengaruh Kompensasi Eksekutif terhadap Agresivitas Pajak}

Berdasarkan tabel 7 , besar nilai probabilitas dari variabel kompensasi eksekutif sebesar 0,0610>0,05 dan koefisien variabel kompensasi eksekutif sebesar 0,091770 dengan nilai positif, artinya variabel kompensasi eksekutif tidak berpengaruh signifikan terhadap agresivitas pajak pada perusahaan pertambangan yang terdaftar di Bursa Efek Indonesia periode 2011-2017.

Para pemegang saham berharap adanya peningkatan kinerja oleh manajemen, oleh karena itu pemegang saham memberikan motivasi berupa kompensasi yang besar atas kinerja perusahaan yang baik. Teori agensi menekankan pada kontrak antara pemegang saham dengan manajemen 
dimana terdapat asimetri informasi. Manajemen lebih menguasai informasiinformasi vital perusahaan dibanding para pemegang saham perusahaan. Atas dasar keinginan memiliki kompensasi yang lebih besar dan adanya asimetri inforrmasi tersebut manajemen akan berusaha untuk melakukan apa saja secara lebih leluasa agar kinerja perusahaan meningkat, seperti salah satunya melakukan tindakan agresif terhadap pajak agar beban pajak kecil dan laba perusahaan meningkat. Sehingga semakin tinggi kompensasi yang diterima, maka manajemenpun akan cenderung melakukan tindakan agresif pajak. Namun sistem pemberian kompensasi pada perusahaan pertambangan periode 2011-2017 kurang dapat mendorong manajemen untuk melakukan tindakan agresif terhadap pajak.

\section{Tabel 8}

Perbandingan antara Agresivitas Pajak dengan Kompensasi Eksekutif

\begin{tabular}{|c|c|c|}
\hline & $\begin{array}{c}\text { Sampel } \\
\text { dengan } \\
\text { ETR }<25 \%\end{array}$ & $\begin{array}{c}\text { Sampel } \\
\text { dengan } \\
\text { ETR }>25 \%\end{array}$ \\
\hline $\begin{array}{c}\text { Sampel KE }< \\
\text { Mean }(23,963)\end{array}$ & 2 & 28 \\
\hline $\begin{array}{c}\text { Sampel KE > } \\
\text { Mean (23,963) }\end{array}$ & 6 & 20 \\
\hline
\end{tabular}

Sumber: Data diolah penulis (2019)

Didukung dengan hasil analisa statistik deskriptif pada tabel 8, diantara 26 sampel yang memiliki kompensasi di atas rata-rata, hanya terdapat 6 sampel yang diindikasikan melakukan tindakan agresivitas pajak, sedangkan sisanya sebanyak 20 sampel tidak melakukan tindakan agresivitas pajak. Hal ini bertentangan dengan hipotesis penelitian, bahwa kompensasi eksekutif tidak berpengaruh signifikan dengan agresivitas pajak sesuai dengan penelitian Puspita, $S$. R. (2015).

\section{Pembahasan Pengaruh Direktur Independen terhadap Agresivitas Pajak}

Berdasarkan tabel 7 , nilai probabilitas yang dimiliki oleh direktur independen adalah sebesar 0,1258>0,05 dengan koefisien sebesar $-0,150288$ yang berarti direktur independen tidak berpengaruh signifikan terhadap agresivitas pajak pada perusahaan pertambangan yang terdaftar di Bursa Efek Indonesia periode 2011-2017.

Direktur independen memiliki tugas penting dalam perusahaan di tatanan eksekutif. Sebagai direktur yang tidak terafiliasi dan ketergantungan secara ekonomis terhadap perusahaan, direktur independen dapat menjalankan tugasnya untuk membantu pemegang saham untuk mengatasi agency problem yang terjadi dengan melakukan kontrol atas manajemen sesuai dengan peraturan $\mathrm{BEI}$ No.I.A tentang pencatatan Saham dan Efek Bersifat Ekuitas pada bagian III.1.5. Dengan adanya direktur independen, direktur lainnya akan lebih sulit untuk melakukan kegiatan-kegiatan menyimpang seperti tindakan agresif terhadap pajak untuk meningkatkan kinerja perusahaan yang memberikan keuntungan pribadi bagi direktur lainnya. Namun pada penelitian di perusahaan pertambangan periode 2011-2017, jumlah direktur independen tidak cukup untuk mencegah manajemen melakukan tindakan agresivitas pajak.

\section{Tabel 9}

\section{Perbandingan antara Agresivitas Pajak} dengan Direktur Independen

\begin{tabular}{|c|c|c|}
\hline & $\begin{array}{c}\text { Sampel } \\
\text { dengan } \\
\text { ETR }<25 \%\end{array}$ & $\begin{array}{c}\text { Sampel } \\
\text { dengan } \\
\text { ETR }>25 \%\end{array}$ \\
\hline $\begin{array}{c}\text { Sampel } \\
\text { dengan } \\
\text { DI }<\text { Mean } \\
(0,078)\end{array}$ & 7 & 33 \\
\hline $\begin{array}{c}\text { Sampel } \\
\text { dengan } \\
\text { Dl }>\text { Mean } \\
(0,078)\end{array}$ & 1 & 15 \\
\hline
\end{tabular}

Sumber: Data diolah penulis (2019)

Hal ini didukung dengan hasil analisis statistik deskriptif yang ada pada tabel 9, dari 40 sampel yang memiliki nilai direktur independen di bawah nilai mean, hanya terdapat 7 sampel yang diindikasikan melakukan tindakan agresif pajak, sedangkan sisanya 33 sampel cenderung tidak melakukan tindakan agresif pajak. $\mathrm{Hal}$ ini bertentangan dengan hipotesis penelitian bahwa pengaruh direktur 
independen terhadap agresivitas pajak tidak berpengaruh signifikan sesuai dengan penelitian Tiaras, I., \& Wijaya, $\mathrm{H}$. (2015).

\section{Pembahasan Pengaruh Kualitas Audit terhadap Agresivitas Pajak}

Berdasarkan tabel 7, nilai probabilitas yang dimiliki oleh kualitas audit adalah sebesar $0.0023<0,5$ dengan koefisien -0,060994 yang berarti variabel kualitas audit berpengaruh signifikan dan memiliki arah negatif terhadap tindakan agresif pajak pada perusahaan pertambangan yang terdaftar di Bursa Efek Indonesia periode 2011-2017.

Kualitas audit pada penelitian ini dinilai dari KAP yang memberikan jasa audit kepada perusahaan. Jasa audit yang diberikan oleh KAP yang terafiliasi dengan KAP big four dinilai lebih memiliki kualitas lebih baik dibandingkan dengan non big four karena KAP big four tidak memiliki ketergantungan ekonomi kepada tiap kliennya sebab ukuran KAP yang sudah besar serta memiliki aset yang lebih banyak dan juga KAP tersebut memiliki nama baik yang harus dijaga untuk keberlangsungan KAP tersebut. Oleh karena itu KAP yang termasuk dalam big four akan berusaha untuk menjaga tingkat independensinya, sehingga akan bersifat lebih skeptis terhadap laporan keuangan klien sehingga membuat manajemen memiliki ruang yang terbatas untuk melakukan tindakan agresif terhadap pajak terlebih lagi tindakan yang melanggar peraturan yang ada.

Tabel 10

Perbandingan antara Agresivitas Pajak dengan Kualitas Audit

\begin{tabular}{|c|c|c|}
\hline & $\begin{array}{c}\text { Sampel } \\
\text { dengan } \\
\text { ETR }<25 \%\end{array}$ & $\begin{array}{c}\text { Sampel } \\
\text { dengan } \\
\text { ETR }>25 \%\end{array}$ \\
\hline $\begin{array}{c}\text { Klien KAP Big } \\
\text { Four }\end{array}$ & 6 & 29 \\
\hline $\begin{array}{c}\text { Klien KAP non } \\
\text { Big Four }\end{array}$ & 2 & 19 \\
\hline
\end{tabular}

Sumber: Data diolah penulis (2019)
Hal ini didukung dengan hasil penelitian statistik deskriptif pada tabel 10, dari 35 sampel yang diaudit oleh KAP big four, 29 sampel di antaranya cenderung tidak melakukan tindakan agresif pajak. Menguatkan bahwa manajemen dalam perusahaan yang diaudit KAP big four memiliki ruang terbatas untuk melakukan tindakan agresif pajaknya, sehingga dapat disimpulkan bahwa kualitas audit berpengaruh negatif terhadap agresivitas pajak sesuai dengan hipotesis penelitian dan penelitian yang dilakukan oleh Nurfadilah dkk, (2016) dan Khairunisa, K. dkk, (2017).

\section{KESIMPULAN}

Berdasarkan pengujian yang telah dilakukan, kesimpulan yang dapat diperoleh adalah sebagai berikut:

\section{Analisis Statistik Deskriptif}

Kompensasi eksekutif memiliki nilai minimum sebesar 22.1549, yaitu perusahaan RUIS pada tahun 2011 dan nilai maksimumnya sebesar 26,5465 yaitu perusahaan ADRO pada tahun 2017. Rata-rata dari variabel ini sebesar 23.9632 dengan standar deviasinya sebesar 1.0622, dimana mean lebih besar dari standar deviasi yang menggambarkan keadaan data yang cenderung berkelompok.

Direktur independen mempunyai nilai minimum sebesar 0 yaitu sebanyak 40 sampel dari 56 dan mempunyai nilai maksimum sebesar 0,3333 yaitu perusahaan RUIS sejak tahun 2014 sampai dengan tahun 2017. Nilai mean dari variabel ini sebesar 0.0702 dengan standar deviasi 0,1165 yang menggambarkan data yang tidak berkelompok karena nilai rata-rata yang lebih kecil dari standar deviasi.

Kualitas audit merupakan variabel dummy, dimana sampel akan mendapatkan nilai 1 jika perusahaan sampel diaudit oleh auditor yang terafiliasi dengan KAP Big Four dan mendapat nilai 0 jika diaudit oleh KAP selain KAP yang 
terafiliasi dengan KAP Big Four. Terdapat 21 sampel yang mendapat nilai 0 dan 35 sampel mendapat nilai 1 .

\section{Pengujian Hipotesis Secara Simultan}

Besaran taraf signifikansi $\operatorname{prob}(F$ statistic) sebesar 0,000376 < 0,05, maka dapat disimpulkan variabel kompensasi eksekutif, direktur independen, dan kualitas audit dengan variabel kontrol leverage berpengaruh secara simultan terhadap agresivitas pajak pada perusahaan pertambangan yang terdaftar di Bursa Efek Indonesia periode 20112017. Uji koefisien determinasi $\left(R^{2}\right)$ sebesar 0,274861 atau sebesar $27,4861 \%$, artinya adalah variabel kompensasi eksekutif, direktur independen dan kualitas audit dengan variabel kontrol leverage mempengaruhi agresivitas pajak yang dihitung dengan ETR sebesar $27,4861 \%$ dan sisanya sebesar $72,5139 \%$ dijelaskan oleh faktor lain di luar variabel penelitian.

\section{Pengujian Hipotesis Secara Parsial}

Kompensasi eksekutif tidak berpengaruh signifikan terhadap agresivitas pajak pada perusahaan pertambangan yang terdaftar di Bursa Efek Indonesia periode 2011-2017.

Direktur independen tidak berpengaruh signifikan terhadap agresivitas pajak pada perusahaan pertambangan yang terdaftar di Bursa Efek Indonesia periode 2011-2017.

Kualitas audit berpengaruh signifikan dengan arah negatif terhadap agresivitas pajak pada perusahaan pertambangan yang terdaftar di Bursa Efek Indonesia periode 2011-2017.

\section{IMPLIKASI DAN KETERBATASAN}

Hasil penelitian dari 3 variabel independen yang diteliti, yaitu kompensasi eksekutif, direktur independen dan kualitas audit terhadap agresivitas pajak, yang berpengaruh secara signifikan adalah kualitas audit. Sehingga ini merupakan indikator untuk perusahaan agar memperhatikan variabel kualitas audit karena berpengaruh signifikan terhadap agresifitas pajak.

Penelitian ini terbatas pada perusahaan pertambangan yang terdaftar di Bursa Efek Indonesia saja dengan variabel dependen agresivitas pajak dan variabel independen kompensasi eksekutif, direktur independen dan kualitas audit. Periode penelitian juga hanya selama 7 tahun penelitian, sehingga pengembangan penelitian ini masih sangat mungkin dilakukan mengingat masih banyak faktor yang mempengaruhi agresivitas pajak.

Saran yang dianjurkan kepada peneliti selanjutnya agar melakukan penelitian dengan menggunakan objek penelitian perusahaan sektor lainnya seperti manufaktur dan lain-lain. Untuk variabel independennya dapat menggunakan CSR Disclosure atau struktur kepemilikan perusahaan. Juga untuk periode penelitian dapat ditambahkan beberapa tahun lagi untuk mengembangkan penelitian.

\section{REFERENCES}

Badan Pusat Statistik. (2018, Juni 28). Realisasi Penerimaan Negara (Milyar Rupiah), 2017-2018. Dipetik Oktober 4, 2018, dari bps.go.id: https://www.bps.go.id/statictable/20 09/02/24/1286/realisasi-

penerimaan-negara-milyar-rupiah2007-2018.html

Fadhila, N., Pratomo, D., \& Yudowati, S. (2017). Pengaruh Manajerial, Komisaris Independen dan Komite Audit Terhadap Tax Avoidance. EJurnal Akuntansi Universitas Udayana Vol.21.3. 2302-8556, 1803-1820.

Halioui, K., Neifar, S., \& Abdelaziz, F. (2016). Corporate governance, CEO compensation and tax aggressiveness: Evidence from American firms listed on the NASDAQ 100. Review of Accounting and Finance, 15, 445-462.

Hanafi, U., \& Harto, P. (2014). Analisi Pengaruh Kompensasi Eksekutif, 
Kepemilikan Saham Eksekutif dan Preferensi Risiko Eksekutif terhadap Penghindaran Pajak Perusahaan. Diponegoro Journal of Accounting, 3, 1-11.

Khairunisa, K., Hapsari, D. W., \& Aminah, W. (2017). Pengaruh Kualitas Audit, Corporate Social Responsibility dan Ukuran Perusahaan Terhadap Tax Avoidance. Jurnal Riset Akuntansi Kontemporer Vol 9, No.1 ISSN 2068-5091, 36-43.

Martani, D., \& Rusydi, M. (2014). Pengaruh Struktur Kepemilikan Terhadap Aggressive Tax Avoidance. SNA 17 Mataram, Lombok 24-27 Sept.

Mardiasmo. (2016). Perpajakan Edisi 2016. Yogyakarta: Andi Yogyakarta.

Nurfadilah, Mulyati, H., Purnamasari, M., \& Niar, H. (2016). Pengaruh Leverage, Ukuran Perusahaan dan Kualitas Audit Terhadap Penghindaran Pajak. Syariah Paper Accounting FEB UMS ISSN 2460-0784, 441449.

Perkasa, A. (2017, November 20). 6.080 WP di Sektor Migas dan Minerba Diduga Kemplang Pajak. Dipetik Oktober 24, 2018, dari www.cnnindonesia.com:

https://www.cnnindonesia.com/ekon omi/20171120122556-532256840/6080-wp-di-sektor-migasdan-minerba-diduga-kemplangpajak.

Primandita, Yuda Aryanto, Agus Puji Priyono, (2015). Kompilasi UndangUndang Perpajakan Terlengkap. Salemba Empat

Puspita, S. R. (2015). Pengaruh Tata Kelola Perusahaan Terhadap Penghindaran Pajak. Diponegoro Journal of Accounting, 3.

Santoso, T., \& Muid, D. (2014). Pengaruh Corporate Goverance Terhadap Penghindaran Pajak Perusahaan. Diponegoro Journall of Accounting ISSN: 2337-3806, 1-11.

Sunardi, d. P. (2015). Bisnis Pengantar (Konsep, Strategi, dan Kasus). Yogyakarta: CAPS.
Tiaras, I., \& Wijaya, H. (2015). Pengaruh Likuiditas, Leverage, Manajemen Laba, Komisaris Independen dan Ukuran Perusahaan terhadap Agresivitas Pajak. Jurnal Akuntansi Fakultas Ekonomi Universitas Tarumanagara Jakarta, XIX, 380397. 